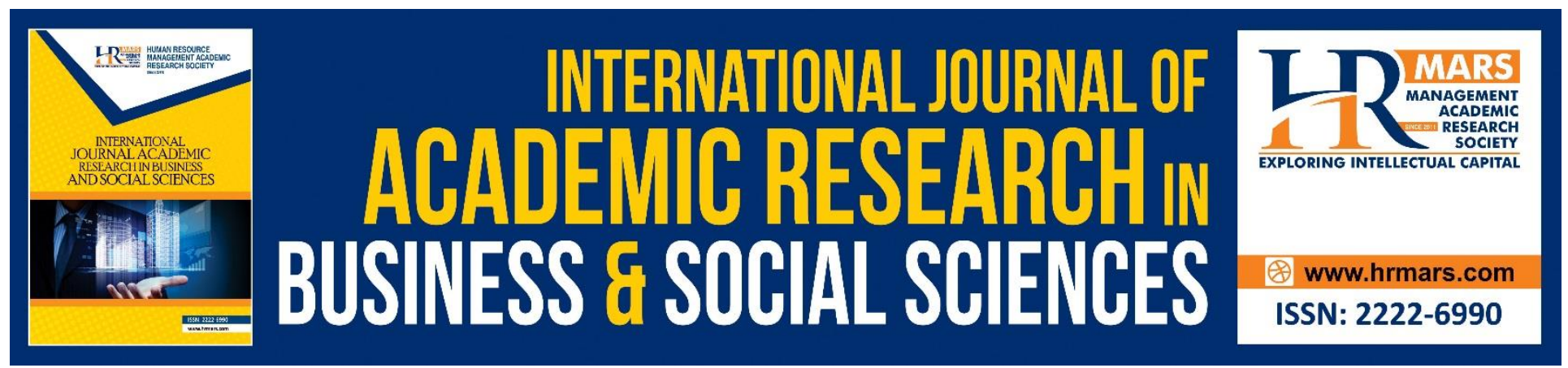

\title{
Relationship of Attitude Factors to Engagement in Physical Education among Secondary School Students
}

\section{Mawarni Mohamed and Nik Afiqah Kamil}

To Link this Article: http://dx.doi.org/10.6007/IJARBSS/v10-i14/7686

DOI:10.6007/IJARBSS/v10-i14/7686

Received: 03 April 2020, Revised: 07 May 2020, Accepted: 13 June 2020

Published Online: 21 July 2020

In-Text Citation: (Mohamed \& Kamil, 2020)

To Cite this Article: Mohamed, M., \& Kamil, N. A. (2020). Relationship of Attitude Factors to Engagement in Physical Education among Secondary School Students. International Journal of Academic Research in Business and Social Sciences, 10(14), 171-180.

Copyright: (C) 2020 The Author(s)

Published by Human Resource Management Academic Research Society (www.hrmars.com)

This article is published under the Creative Commons Attribution (CC BY 4.0) license. Anyone may reproduce, distribute, translate and create derivative works of this article (for both commercial and non-commercial purposes), subject to full attribution to the original publication and authors. The full terms of this license may be seen at: http://creativecommons.org/licences/by/4.0/legalcode

Special Issue: WSTI2018 - Issues and Trends on Education, Science and Technology, 2020, Pg. 171 - 180 http://hrmars.com/index.php/pages/detail/IJARBSS

Full Terms \& Conditions of access and use can be found at http://hrmars.com/index.php/pages/detail/publication-ethics 


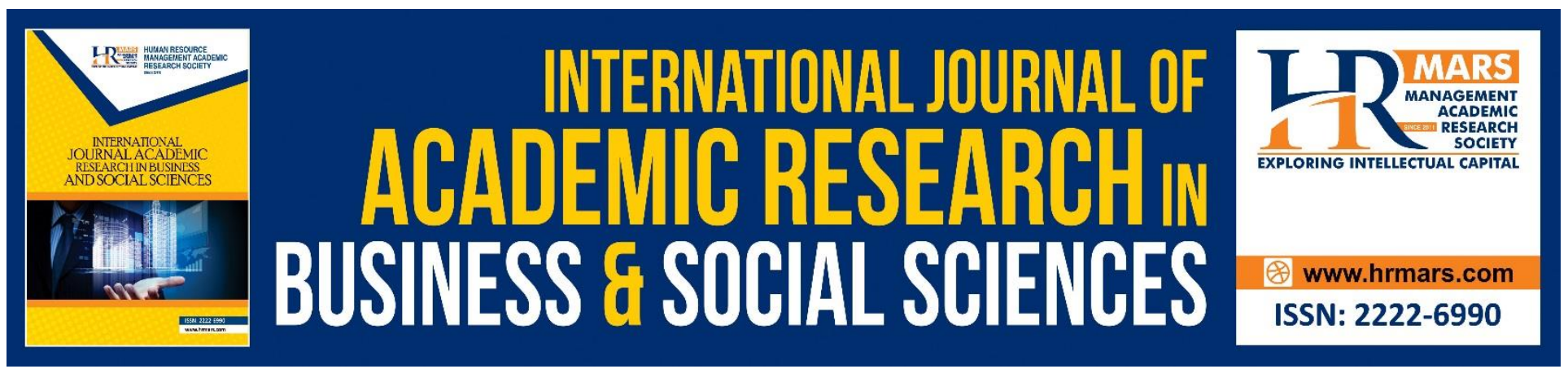

\title{
Relationship of Attitude Factors to Engagement in Physical Education among Secondary School Students
}

\author{
Mawarni Mohamed ${ }^{1}$ and Nik Afiqah Kamil ${ }^{2}$ \\ ${ }^{1,2}$ Faculty of Education, Universiti Teknologi MARA (UiTM), Puncak Alam Campus, Selangor Branch, \\ Malaysia
}

\begin{abstract}
The purpose of this study is to determine students' attitude towards the implementation of Physical Education in secondary schools. It is also to identify the relationship between students' attitude and the following factors in Physical Education, namely the objective, content of curriculum, teachers, teaching period and equipment and facilities in schools. A sample random technique consists of 322 Form Four secondary school students in Selangor were selected. A set of questionnaires was used to assess students' attitudes and factors that influence that attitude towards the implementation of Physical Education in school. Descriptive statistical analysis and correlation analysis were employed to analyze the data. Results of this study showed that the mean score value of students' attitude towards implementation of Physical Education was high. The correlation analysis showed that factors such as Physical Education objective, contents of curriculum, Physical Education teachers, teaching period and equipment and facilities had significant positive relations with students' attitudes. The results of this study provide useful information about the existing attitudes of students towards PE implementation. Recommendations for educational leadership and PE teachers are made based on the findings.
\end{abstract}

Keywords: Attitudes, Physical Education.

\section{Introduction}

Physical education (PE) is an important subject in curriculum of formal education system in Malaysia (Azjen, 1993) and recognized as one of the most important activities to develop the habit of physical activity during adolescence (Alcala \& Garijo, 2017) and also helps to improve the students' ability through physical activity, social, emotional and cognitive development (Awang, 2012). However, as a non-examination subject, PE is perceived as lesser values, boring and not capable of providing valuable outcomes to students.

Even though the issue of this subject taught by teachers who are not specially trained in Physical education and lack of detailed evaluation system still exist, however, the awareness towards 
the importance of Physical Education has increased. The curriculum of Physical Education for example, has been revised to ensure student mastery on knowledge and skills of the subject are increasing (Aziz, 2005). A more effective and holistic approach in teaching PE should be implemented by involving students in at least one game or sport in school (Balakrishnan et al., 2011). Other aspects like suitability length of teaching time, facility and equipment provided and teachers' qualifications contribute to the effective instruction of PE classes.

Despite the efforts, students' achievement and participation in PE class are still low. Students escape themselves by playing truant, skipping classes as well as being free from teachers' monitor and supervision. Additionally, some students are only interested to one kind of games or sport only, like football and they do not want to get involved with other kind of sport.

These attitudes represent student's acceptance towards Physical Education subject, in which in general Physical Education subject is seen as non-important subject, and teachers show less commitment to attract students, especially when they are not majoring in PE. In some cases, there are also schools where PE classes are replaced with other subjects that are considered more important for exam preparation. Furthermore, from the community perspective, sports involve active commitment from male students (Bari \& Ali, 2005) which contributes to less participation in PE class especially among the female students.

Attitudes exist along the direction from negative to positive and are formed through beliefs. Understanding attitudes influence whether we should continue with certain activities or what we achieve in certain areas (Crawford et al., 1991) because our actions also have an influence on our thoughts and feelings. Therefore, this study aims to investigate students' attitude towards the implementation of Physical education in schools and to identify if the attitudes are related to the following factors: Physical Education teaching objective, content of curriculum, Physical Education teachers, teaching period and facilities and equipment in schools.

\section{Review of Literature}

Attitudes toward physical education can be initiated in the early phase of age. It can be transformed based on the situation in students' life such as their class environment of physical and health education (Earls, 1981). Attitude can also give notice effect toward some related issues such as object of attitudes, recall of attitude applicable information and judgment, and in interpretation of encoding information category (Flintoff, 1991).

A theory that is related to this study is Hierarchical Model of Attitude Theory (Hagger et al., 2001). This theory described that attitudes are the individual character to respond with a certain degree of favorableness or favorableness to person, event, object or behavior. There are pros and cons or negative and positive characteristic in attitudes. In this model theory, attitude is the multidimensional term that obtains cognition, affects, and conation as the independently component. Meanwhile, each component is invented from verbal and nonverbal reaction response class. So, if a student has positive experience in physical education and develops a positive attitude about physical activity, motivation to engage in it outside classroom is likely to occur (Hashim et al., 2003). 
Many researches have been conducted about students' attitudes and findings suggested that students have favorable attitudes toward the subject (Jani, 2006). However, other factors seemed to give impact towards students' favorableness. This include teachers and PE curriculum. In this context, teachers' behaviors and enjoyable curriculum have positive relation to students' attitudes (Luke \& Sinclair, 1991; Matanin \& Collier, 2003). Thus, this study is based on the theoretical structure in the implementation of physical and health education in schools from human factor and non-human factor. The first factor of the implementation of physical and health education involves with an administrator, teachers, and staff in schools and the second factor of implementation physical and health education involves books, facilities, space, and equipment (Mitchell, 1993).

\section{Methodology}

A quantitative survey design was employed to seek information and data on students' attitudes towards the implementation of Physical Education subject in secondary schools in Selangor and its relationship with the following factors: Physical Education objective, content of curriculum, Physical Education teachers, teaching period and facilities and equipment in schools that determine their attitudes. Using a simple random sampling technique, a total of 322 students in five secondary schools in Shah Alam were involved in this research. 12 items of questionnaire for "Students' Attitudes towards Physical Education" was used. The instruments have been widely used in research evaluating attitudes toward Physical Education and the reliability of the Wear's Inventory has a total score of +.80 (Neo et al., 2014). A pilot test conducted has shown a reliability value of 0.87 . Descriptive analysis and Pearson Correlation were used to analyze the attitudes of students toward PE class and the relationship with factors affecting the attitudes

\section{Results and Discussions}

The results of the level of student's attitudes towards the Implementation of physical Education according to the total of mean score value is shown in Table 1. 
INTERNATIONAL JOURNAL OF ACADEMIC RESEARCH IN BUSINESS AND SOCIAL SCIENCES

Vol. 10, No. 14, Special Issue: WSTI2018 - Issues and Trends on Education, Science and Technology, 2020, E-ISSN: 2222-6990 @ 2020 HRMARS

Table 1: Levels of Student's Attitude towards Physical Education Subject

\begin{tabular}{|c|c|c|c|}
\hline Statement & Mean & SD & Level \\
\hline I am happy to be in Physical Education class. & 4.31 & .613 & High \\
\hline $\begin{array}{l}\text { For me, Physical Education class is very interesting and I am eager } \\
\text { to follow it. }\end{array}$ & 4.27 & .575 & High \\
\hline In my opinion, Physical Education is not a boring subject. & 4.40 & .584 & High \\
\hline $\begin{array}{l}\text { My involvement in Physical Education class gives satisfaction and } \\
\text { fun to me. }\end{array}$ & 4.40 & .578 & High \\
\hline $\begin{array}{l}\text { I always advise my friends to concentrate in Physical Education } \\
\text { class. }\end{array}$ & 4.42 & .592 & High \\
\hline I will feel sorry if I miss Physical Education class. & 4.27 & .595 & High \\
\hline I care towards Physical Education taught in school. & 4.38 & .558 & High \\
\hline $\begin{array}{l}\text { If given chance to select subjects taken in school, I would } \\
\text { choose Physical Education in the first place. }\end{array}$ & 4.44 & .504 & High \\
\hline I always have active participation in Physical Education class. & 4.39 & .591 & High \\
\hline Physical Education is equally important with other subjects. & 4.39 & .577 & High \\
\hline Learning period of Physical Education should be increased. & 4.47 & .553 & High \\
\hline Physical Education should be an examination subject. & 4.22 & .667 & High \\
\hline Total Mean & 4.36 & .300 & High \\
\hline
\end{tabular}

Note : $\mathrm{M}=$ Mean, $\mathrm{SD}=$ Standard Deviation, Low (1.00-2.33), Moderate (2.34-3.67), High (3.68-5.00)

Results indicated that respondents showed positive attitudes of PE subject with an overall mean score of $(M=4.36, S D=0.300)$. The item that records the highest mean value is "Learning period of Physical education should be increased." with the mean score of ( $M=4.47, S D=0.553)$, followed by "If given a chance to select subjects taken in school, I would choose Physical Education in the first place." with mean score values $(M=4.44, S D=0.504)$. Followed by item "I always advise my friends to concentrate in Physical Education class." with mean score value ( $M=4.42, S D=0.592)$. The two items respectively records the same value of mean score $(M=4.40)$ are item "In my opinion, Physical Education is not a boring subject." (SD=0.584) and "My involvement in Physical Education class gives satisfaction and fun to me." $(\mathrm{SD}=0.578)$, which indicate that students generally enjoy PE class. Meanwhile, the item which recorded the lowest mean score is "Physical education should be an examination subject." with a mean score of $(M=4.22, S D=0.667)$.

The results of the data indicated that overall student's attitude toward the implementation of Physical Education is located at a high level. An average of student attitude analysis found in this study that the respondents quite comfortable with the teaching of Physical education system that exist today. However, the concern issue in this aspect is on whether "Physical education should be an examination subject." which had the lowest mean score. This shows that students are still unable to comprehend the teaching content as something important andtheir understanding is reviewed through test. 
INTERNATIONAL JOURNAL OF ACADEMIC RESEARCH IN BUSINESS AND SOCIAL SCIENCES

Vol. 10, No. 14, Special Issue: WSTI2018 - Issues and Trends on Education, Science and Technology, 2020, E-ISSN: 2222-6990 @ 2020 HRMARS

The pearson correlation analysis was used to identify the relationship between the students' attitude towards the implementation of Physical education and the influencing factors. Based on the study conducted, results from the feedback of the respondents are shown in Table 2.

Table 2: Correlation Between Students' attitude Towards The Implementation of Physical education and The Influencing Factors.

\begin{tabular}{|c|c|c|c|c|c|c|}
\hline & $\begin{array}{l}\text { Attitude } \\
\text { S }\end{array}$ & Objective & $\begin{array}{l}\text { Curriculu } \\
\mathrm{m}\end{array}$ & Teachers & $\begin{array}{l}\text { Teaching } \\
\text { Period }\end{array}$ & $\begin{array}{l}\text { Facilities \& } \\
\text { Equipment's }\end{array}$ \\
\hline Attitudes & 1 & $.662 * *$ & $.560 * *$ & $.709 * *$ & $.585^{* *}$ & $.622 * *$ \\
\hline Sig. (2-tailed) & & .000 & .000 & .000 & .000 & .000 \\
\hline Objective & & 1 & $.377 * *$ & $.824 * *$ & $.623 * *$ & $.803^{* *}$ \\
\hline Sig. (2-tailed) & & & .000 & .000 & .000 & .000 \\
\hline Curriculum & & & 1 & $.733^{* *}$ & $.766 * *$ & $.674 * *$ \\
\hline Sig. (2-tailed) & & & & .000 & .000 & .000 \\
\hline Teachers & & & & 1 & $.813^{* *}$ & $.867^{* *}$ \\
\hline Sig. (2-tailed) & & & & & & .000 \\
\hline Teaching Period & & & & & 1 & $.811^{* *}$ \\
\hline Sig. (2-tailed) & & & & & & .000 \\
\hline $\begin{array}{l}\text { Facilities } \\
\text { Equipment }\end{array}$ & \& & & & & & 1 \\
\hline
\end{tabular}

Table 2 shows that all the influencing factors indicate significant relationship between students' attitudes. Table 3 highlights the variables that influence students' attitudes on PE implementation. It signifies a significant relationship between students' attitudes and the objectives of PE subject, curriculum, teachers, teaching period and facilities and equipment.

Table 3: Correlation Between Students' attitude Towards The Implementation of Physical education and The Influencing Factors.

\begin{tabular}{|c|c|c|c|}
\hline Variables & Correlation Coefficient, $r$ & Interpretation & Level \\
\hline Attitudes and Objective & $.662 * *$ & Strong & Positive \\
\hline Attitudes and Curriculum & $.560 * *$ & Strong & Positive \\
\hline Attitudes and Teachers & $.709 * *$ & Very Strong & Positive \\
\hline Attitudes and Teaching Period & $.585^{* *}$ & Strong & Positive \\
\hline $\begin{array}{l}\text { Attitudes and Facilities \& } \\
\text { Equipment's }\end{array}$ & $.622 * *$ & Strong & Positive \\
\hline
\end{tabular}

The data shows that there is a strong positive correlation between students' attitude towards Physical education and Physical Education Teaching Objective $(r=.662$, $p$-value $=.000)$. It means, the aims of PE to help students to be active and to educate them through physical activities are well received. There is also a positive correlation between students' attitude towards Physical education and the content of curriculum $(r=.560, p$-value $=.000)$. The aims as specified by the Curriculum Development Division $(1999,2001)$ provides positive impact on the implementation of PE. Various methods proposed for the teaching of Physical Education has helped to enhance more positive 
attitudes toward learning. For example, TGFU approach is seen to have improved students' tactical skills, motivation, and achievement perception in PE (Rink, 2006; Sallis \& McKenzie, 1991).

This means that appropriate teaching approach selection with the students' ability is very vital because it can help students' understanding and learning. Effective interaction between students and teachers is essential if the teacher want learning outcomes to become more excellent. In terms of the curriculum, students believed that the contents taught in PE syllabus are relevant. This means the appropriateness or relevance of the content as well as teaching reference source meets the requirements. These results suggest that curriculum aspects and the content have a relatively strong relationship. In addition, the emphasis should also be given to interesting lesson plans and content material in line with the needs of students, the curriculum should be more independent and able to adapt to changing needs and current environment. Results suggest that the teacher and the curriculum have been found to influence student attitudes toward physical education.

There is a very strong positive correlation $(r=.709, p$-value $=.000)$ between students' attitude towards PE class and Physical Education teachers. Since teachers are vital person in delivering knowledge to students, they become models to show exemplary positive attitude towards the subject taught. Although less specific studies about the influence of teachers on students' attitudes towards Physical Education have been carried out, concerns that exist in the Ministry of Education, among the public and also among the students are enough to show the influence of teachers and learning environment on students' attitude towards PE class.

A learning environment that promotes personal meaning is important to the development of positive attitudes (Sanes, 2010). Students are also likely to become more positive toward physical activity if they feel comfortable and confident (Silverman \& Subramaniam, 1999). This shows that the role and teachers' involvement in the implementation of the Physical Education is important because teachers motivate students to be physically active and take the role of physical activity director for the school. Furthermore, distinctive teachers who concern for their pupils affect the decisions of teachers in all aspects of their job, it fosters both gradual and dramatic changes in the learning and behavior of teachers (Baker et al., 2003). It seems, the Ministry of Education (MOE) and its agencies are committed towards training and re-training its physical education teachers to further enhance the quality of teaching. In fact, under the $10^{\text {th }}$ Malaysia Plan 2011-2015, the number of physical education teachers graduates continued to increase.

Therefore, to increase the level of Physical Education implementation in schools, especially in secondary schools, all aspects related to the role and involvement of teachers need to be emphasized and given major concern. For example, a teacher must master the content knowledge to execute effective teaching, thus teachers teaching PE majoring in sports or physical and health education is an advantage. The teacher with high content of knowledge can drive the teaching and learning process more effectively in reaching the objectives, making the lessons more meaningful and motivational.

Besides, high content knowledge and pedagogical method like classrooms management, the usage of teaching aid at optimum level can give full positive impact towards teaching and achieving 
the objectives of the lessons (Stelzer, 2004). The PE teachers' training curriculum has been strengthened to develop PE teachers as competent managers of teaching and learning. The skills that the physical education teachers have are important assets to help the teaching and students learning and improve the students' potential in learning process,

Furthermore, teaching period factor also recorded to have a strong positive relationship on attitudes towards Physical Education. Based on this result, it was found that longer time spent on PE classes at present ( 2 hours per week as stipulated by MOE) gives more time for the preparation to the field, for teachers to teach certain skills and brings more enjoyment to the students in the field. For example, an allocation of an hour for PE class per period as compared to only 40 minutes brings seemed to bring positive outcome.

Good plan will maximize the time provided (Subramaniam \& Silverman, 2000). Thus, the time provided should be used entirely to execute effective lesson. Efficient use of time is one aspect of pedagogy that contributes to efficient lessons (Vogel et al., 2014). While preparing for the lessons, teachers must act wisely on time management so that the time spent on subtopic and important contents are suitable. As known, there is induction, warm-ups activity, teachers' demonstration, students' demonstration, class workout, group workout, games, cooling-down activity and closure. All of these activities are the main components in execution of Physical Education subject in secondary schools.

Other study (Wee, 2000) found that from the time provided for Physical education allocated only $27 \%$ for actual content related meanwhile $75 \%$ was on administrative matters like waiting for the students, calming the students and preparing the space for the activities. So, a total 40 minutes of Physical education provided, only 2 and half minute is spent to actual learning on the content. Therefore, allocating more time for PE subject which has been implemented in many schools now provides more impact on students' active involvement, which has shown a significant positive relation towards students' attitudes and teaching period in PE.

Facilities and equipment available in school is one of the factors that can influence perceptions and students' attitudes towards Physical Education in school. Strong positive relationship was also found between the respondents' attitudes to the facilities and equipment factors. Since the research was conducted in a town in Selangor where schools are mostly equipped with good facilities, therefore students felt that they have the chance to use sports equipment and in their view the equipment was relevant and sufficient for use. This factor may not be applicable for schools in the rural areas where equipment and facilities are major issues in PE implementation. This is because the availability of adequate facilities and equipment with their utilization play important factors in developing positive attitudes toward PE among students. If these resources are lacking, the effective functioning of the school physical education program will also be hindered

\section{Conclusions}

The results suggest that overall, students enjoy physical education and view that it is important. So, to ensure effective teaching and learning, teaching PE should not only be fun but also based on scientific principles which encompass both the theory and practice where the skill physically 
should be present. Teachers should be continually trained to improve the quality of the teaching and learning process and be given the authority and flexibility to modify in accordance with the current situation in schools and students' preferences. Based on positive attitudes shown by students, Physical Education instructional time added will enable real -time teaching to be carried out more effectively, hopefully across all schools in Malaysia. Equipment and facilities for teaching and learning of physical education in schools need to be updated from time to time so malfunctioned equipment should be replaced, while supplies are to be added in accordance to the number of students in a class. Support from parents and community can help to reduce cost in sponsoring sports equipment through health promotion in schools. Finally, the administrators and school staffs need to demonstrate engagement towards the establishment of a positive perception and attitude towards Physical Education subject among students through the implementation, practice and concern for this subject. Support and encouragement from educational leadership is seen to encourage more uplifting attitudes towards physical activity through PE class, thus help improve the well-being of young generation.

\section{Acknowledgments}

Part of this work was supported by UiTM under Grant Nos 600-IRMI/DANA 5/3/LESTARI (0042/2016).

\section{References}

Ajzen, I. (1993). Attitude Theory and The Attitude-Behavior Relation. New Directions in Attitude Measurement, 41-57.

Alcala, D. H., \& Garijo, A. H. (2017). Teaching Games for Understanding: A Comprehensive Approach to Promote Student's Motivation in Physical Education. Journal of Human Kinetics, 59, 17-27. https://doi.org/10.1515/hukin-2017-0144.

Awang, Z. (2012). Strategi pengajaran mata pelajaran Pendidikan Jasmani yang berkesan. Unpublished dissertation. Universiti Malaya, Kuala Lumpur, Malaysia.

Aziz, M. A. (2005). Tahap pelaksanaan Pendidikan Jasmani dan Kesihatan di SMK Bera, Pahang. Unpublished thesis. Universiti Pendidikan Sultan Idris, Perak, Malaysia.

Baker, J. A., Dilly, L. J., Aupperlee, J. L., \& Patil, S. A. (2003). The developmental context of school satisfaction: Schools as psychologically healthy environments. School Psychology Quarterly, 18(2), 206-221. https://doi.org/10.1521/scpq.18.2.206.21861.

Balakrishnan, M., Rengasamy, S., \& Aman, M. S. (2011). Effect of teaching games for understanding approach on students' cognitive learning outcome. World Academy of Science, Engineering and Technology. International Journal of Educational and Pedagogical Sciences, 5(5), 714-716.

Bari, S., \& Ali, H. M. (2005). Aktiviti Pendidikan Jasmani Suaian Pelajar Berkeperluan Khas. Unpublished manuscript, Universiti Kebangsaan Malaysia, Bangi, Malaysia.

Crawford, D. W., Jackson, E. L., \& Godbey, G. (1991). A hierarchical model of leisure constraints. Leisure sciences, 13(4), 309-320.

Earls, N. (1981). Distinctive teachers' personal qualities, perceptions of teacher education, and realities of teaching. Journal of Teaching in Physical Education, 1(1), 59-70.

Flintoff, A. (1991). Dance, masculinity and teacher education. British Journal of Physical Education, 22(4), 31-35. 
Hagger, M. S., Chatzisarantis, N. L., \& Biddle, J. H. (2002). A meta-analytic review of the theories of reasoned action and planned behavior in physical activity: Predictive validity and the contribution of additional variable. Journal of Sport \& Exercise Psychology, 24, 3-32.

Hashim, S., Yaakub, R., \& Ahmad, M. Z. (2003). Pedagogi (Strategi dan Teknik Mengajar Dengan Berkesan. Pahang, Malaysia: PTS Publications and Distributors Sdn Bhd.

Jani, J. (2006). Peranan Guru dalam Memacukan Pembangunan Sukan di Malaysia. Unpublished manuscript, Universiti Pendidikan Sultan Idris, Perak, Malaysia.

Luke, M. D., \& Sinclair, G. D. (1991). Gender differences in adolescents' attitudes toward school physical education. Journal of Teaching in Physical Education, 11, 31-46.

Matanin, M., \& Collier, C. (2003). Longitudinal Analysis of Preservice Teachers' Beliefs about Teaching Physical Education. Journal of Teaching in Physical Education, 22, 153-168.

Mitchell, M. (1993). Linking teacher educators, knowledge, and the quality of practice in schools. Journal of Teaching in Physical Education, 12, 399-412.

Neo, E. A. T. L., Mohsin, M., Ming, C. C., \& Nadarajah, G. M. (2014). Kurikulum dan Pedagogi Pendidikan Jasmani. Kuala Lumpur, Malaysia: Oxford Fajar Sdn. Bhd.

Rink, J. (2006). Teaching Physical Education for Learning $6^{\text {th }}$ Edition. New York: McGraw-Hill.

Sallis, J. F., \& McKenzie, T. L. (1991). Physical education's role in public health. Research quarterly for exercise and sport, 62(2), 124-137.

Sanes, L. A. C. (2010). Students' Attitudes Toward Physical Education. College of Arts and Sciences. Retrieved from http://local.Isu.edu.ph/institutional_research_office/publications/vol.14no.4/4.html

Silverman, S., \& Subramaniam, P. R. (1999). Student Attitude toward Physical Education and Physical Activity: A Review of Measurement Issues and Outcomes. Journal of Physics Teacher Education, 19, 96-124.

Stelzer, J., Ernest, J. M., Fenster, M. J., \& Langford, G. (2004). Attitudes toward physical education: A study of high school students from four countries-Austria, Czech Republic, England, and USA. College Student Journal, 38, 171-178.

Subramaniam, P. R., \& Silverman, S. (2000). Validation of scores from an instrument assessing student attitude toward physical education. Measurement in Physical Education and Exercise Science, 4, 29- 43.

Vogel, T., Bohner, G., \& Wanke, M. (2014). Attitudes and Attitude Change $2^{\text {nd }}$ Edition. London: Routledge, Taylor and Francis.

Wee, E. H. (2000). Attitude of Administrators and Teachers Towards Physical Education and The Implementation of Physical Education Programs in the Secondary School. Unpublished thesis, Universiti Malaya, Kuala Lumpur, Malaysia. 